\title{
LMP-2:340-349 Peptide Vaccine
}

National Cancer Institute

\section{Source}

National Cancer Institute. LMP-2:340-349 Peptide Vaccine. NCI Thesaurus. Code C62767.

A peptide vaccine containing amino acids residues from 340 through 349 of the latent membrane protein-2 (LMP-2) of the Epstein-Barr virus (EBV) with potential immunostimulating and antineoplastic activities. LMP-2, an EBV transmembrane protein, is expressed in various malignancies including nasopharyngeal cancer and EBV-positive Hodgkin disease. Vaccination with the LMP-2:340-349 peptide may boost the immune system to mount a specific cytotoxic T-lymphocyte $(C T L)$ response against LMP-2 producing cells, resulting in cell lysis and inhibition of cancer cell proliferation. 